\title{
Effect of Acacia albida Pods Associated to Polyethylene Glycol on the In vitro Digestibility of Rice Straw Treated with Banana Leaves Ashes Extract in Goat
}

\author{
Lemoufouet Jules ${ }^{1}{ }^{*}$, Tendonkeng Fernand ${ }^{1}$, Kana Jean Raphael ${ }^{1}$, Miégoué Emile ${ }^{1}$, \\ Mube Kuitche Hervé ${ }^{1}$, Tchio Sah Rodrigue ${ }^{1}$, Mekuiko Watsop Hippolyte ${ }^{1}$, \\ Nathalie Mweugang Ngouopo ${ }^{2}$, Matumuini Ndzani Essie Ference ${ }^{3}$, Pamo Tedonkeng Etienne ${ }^{1}$ \\ ${ }^{1}$ Department of Animal Science, Faculty of Agronomy and Agricultural Sciences, University of Dschang, Dschang, Cameroon \\ ${ }^{2}$ Department of Animal Science, Faculty of Sciences, University of Ngaoundere, Ngaoundere, Cameroon \\ ${ }^{3}$ Higher institute of Agronomy and Biotechnology (INSAB), University of Science and Technology of Masuku, Franceville, Gabon
}

Email address:

juleslemoft@yahoo.fr (L. Jules), jules.lemoufouet@univ-dschang.org (L. Jules)

${ }^{*}$ Corresponding author

\section{To cite this article:}

Lemoufouet Jules, Tendonkeng Fernand, Kana Jean Raphael, Miégoué Emile, Mube Kuitche Hervé, Tchio Sah Rodrigue, Mekuiko Watsop Hippolyte, Nathalie Mweugang Ngouopo, Matumuini Ndzani Essie Ference, Pamo Tedonkeng Etienne. Effect of Acacia albida Pods Associated to Polyethylene Glycol on the In vitro Digestibility of Rice Straw Treated with Banana Leaves Ashes Extract in Goat. International Journal of Animal Science and Technology. Vol. 3, No. 4, 2019, pp. 52-59. doi: 10.11648/j.ijast.20190304.12

Received: October 15, 2019; Accepted: November 15, 2019; Published: December 4, 2019

\begin{abstract}
In order to satisfy the feed requirements of animals in short periods, the integration of livestock to plant production appears as a promising route. Thus, the aim of this work was to evaluate the effect of Acacia albida pods associated to polyethylene glycol on the in vitro digestibility of rice straw treated with extract of ashes of banana leaves, incubated with ruminal fluid from a goat. The study was carried out from March to June 2018 in the Research Unit of Animal Production and Nutrition (URPRONAN) and in the Laboratory of Soil Sciences of the University of Dschang. The rice straw and the banana leaves were harvested in the Agricultural Research Institute for Development (IRAD) of Santchou and Dschang respectively; whereas the Acacia albida pods were collected in the Region of Koundoul, locality situated at $25 \mathrm{~km}$ from Ndjamena in Tchad. At the beginning of the experiment, after the preparation of the ash extract, treatment of rice straw and formulation of the rations, samples were taken in order to determine the chemical composition and evaluate the in vitro digestibility. The results showed that the treatment with ash extract led to an increase in sodium (801 to $900 \mathrm{mg} / \mathrm{kg}$ ), phosphorus (1537.45 mg/kg), calcium (2440 to $11520 \mathrm{mg} / \mathrm{kg}$ ), magnesium (1243 to $1410 \mathrm{mg} / \mathrm{kg}$ ) and potassium (5951.75 to $10276.75 \mathrm{mg} / \mathrm{kg}$ ) content. Contrarily, it induces a decrease in the content of organic matter (from 90.13 to $81.86 \% \mathrm{DM}$ ), lipids (from 1.39 to 0.39 ) and NDF (from 96.44 to 77.57). However, the reverse effect was observed with contents in ash (from 9.96 to $18.13 \% \mathrm{DM}$ ). The complementation of rice straw with Acacia albida pods associated or not to polyethylene glycol significantly $(\mathrm{p}<0.05)$ improved all the parameters of in vitro digestibility of rice straw treated or not, except the partitioning factor (PF) where the values were comparable $(\mathrm{p}>0.05)$. The in vitro digestibility of dry matter and the microbial mass $(\mathrm{MM})$ instead observed a slight decrease. Apart from the residual nitrogen, the highest values of the other parameters of in vitro digestibility were obtained with treated rice straw compared to untreated rice straw. Acacia albida pods associated to polyethylene glycol on the in vitro digestibility of rice straw treated with banana leaves ashes extract improves digestibility's parameters in goat.
\end{abstract}

Keywords: Rice Straw, Banana Leaves, Ash Extract, Acacia Albida, Polyethylene Glycol, Goat, In Vitro Digestibility

\section{Introduction}

The improvement of production and productivity of ruminants especially during difficult periods is a huge preoccupation of developing country. In this line, the use of agricultural by-products may be an interesting alternative to 
increase the food supply in a sustainable way. In addition, the agriculture practiced in all the agro-ecological zones of Africa in general and of Cameroon in particular, generates each year huge quantities of crop residues including the peanut, bean, cowpea and especially the cereal crop residues including corn stubble and rice straw [13]. These residues in general and rice straw in particular could be used for feeding ruminants in order to increase the production of proteins of animal origin.

In fact, rice, the world's second-largest cereal crop, can produce up to about 377 million tonnes of crop residues annually [2]. In Cameroon, national rice production provides about 250,000 tonnes of straw [16]. But only a limited amount of this straw is used in animal feeds when, treated well, these residues of cereal crops could constitute an important feed resource for the improvement of the production of the ruminants with moderate need $[10,13]$. Several methods have been considered to improve its nutritional value, including alkaline treatments such as, $\mathrm{NaOH}, \mathrm{Ca}(\mathrm{OH})_{2}$ and ammonia long used to improve the nutritional value of poor fodder [8]. However, their unavailability, high costs and handling difficulties push agropastoralists to search for available and less expensive products such as ash extract.

Ash, a mainly basic residue from combustion, incineration of various organic and mineral materials can be used for the treatment of poor and poorly digestible forage. Its composition varies according to the calcined product and its origin [16]. With $\mathrm{pH}$ varying according to the fuel used, it turns out that the alkalizing power of the ash extracts remains very high thanks to their high content of lime $\left(\mathrm{Na}_{2} \mathrm{CO}_{3}\right)$ and potassium hydroxide $\left(\mathrm{K}_{2} \mathrm{CO}_{2}\right)$ which could have beneficial effects on the digestibility of the roughage for animal feed.

However, Boka $[20,21]$ reports that treatment alone is insufficient to cover the needs of animals and supplementation with agro-industrial by-products such as molasses is therefore necessary in addition to processing for good production. It could then be a supplement of choice in the diet of ruminants [3]. However, the unavailability of agro-industrial by-products and their high cost limit their use by agro-pastoralists. Woody species could be used as supplementary food for this purpose [22]. These woody species such as Acacia albida, rich in proteins (11.4\% DM) [7], vitamins and minerals are able to qualitatively improve forage rations based on poor forage in the dry season especially in arid areas such as the Northern Cameroon and southern Chad where acacia grows abundantly [4]. Pasture biomass of woody origin is about 35\% [2] and under certain conditions, represents almost all available plant material [5]. For this purpose, pods of Acacia albida can be used as an alternative source of nitrogen for ruminant feeding throughout the difficult season.

In this regard, the work of [5] showed that the addition of Acacia albida pods at $21 \% \mathrm{DM}$ in the ration of minced millet stems and wheat bran improves the average daily gain of $173 \mathrm{~g} /$ day in Gobra bulls. However, the presence of condensed tannins in Acacia albida pods limits their level of incorporation (to about 20\%) in the ration of small ruminants [5]. Thus, to limit the effect of this antinutritional factor, the use of substances such as polyethylene glycol (PEG) capable of fixing the tannins present in the pods is essential in order to facilitate the use of nitrogen by microorganisms of the rumen. However, no studies have yet been conducted on the effect of PEG-associated Acacia albida pods on in vitro digestibility of rice straw treated with ash extract incubated with goat ruminal fluid. It is to fill this gap that this work has been initiated with the main objective of contributing to the improvement of knowledge on the valorization of crop residues in the diet of small ruminants.

\section{Materials and Methods}

\subsection{Presentation of the Study Area}

The study was conducted from March to June 2018 at the Animal Production and Nutrition Research Unit (URPRONAN) and at the Soil Sciences Laboratory of the University of Dschang. The Research and Experimental Farm is located between $5^{\circ} 26^{\prime}-5^{\circ} 44$ 'north latitude and $9^{\circ} 85^{\prime}$ $10^{\circ} 26$ 'east longitude, at an altitude of $1420 \mathrm{~m}$. The climate of the region is equatorial Cameroonian type. Temperatures range from $10^{\circ} \mathrm{C}$ (July-August) to $25^{\circ} \mathrm{C}$ (February) with 1800 hours annual sunshine and $40-97 \%$ relative humidity. The rainfall varies between 1500 and $2000 \mathrm{~mm}$ per year. The dry season runs from mid-November to mid-March and the rainy season from mid-March to mid-November corresponds to the growing season. The original vegetation is a shrubby savannah with some gallery forests [18].

\subsection{Animal Material}

An 18-month-old, empty, adult Guinea dwarf goat purchased at the Dschang market was used as a ruminal fluid donor to study the in vitro digestibility of treated and untreated rice straw with ash extract supplemented with Acacia albida pods associated with PEG.

\subsection{Plant Material}

The plant material consisted of rice straw (residues of the plant remaining in the field after harvest and export of paddy which is unshelled rice) and pods of Acacia albida. The rice straw belonging to the variety NERICA (New Rice for Africa) of low altitude was collected in the plots of the IRAD (Institute of Agronomic Research for Development) at Santchou municipality and transported to the Research and Experimental Farm.

\subsection{Formulation of Rations}

Fourteen (14) rations were used in this study:

R1: untreated rice straw (PRNT: control 1);

R2: untreated rice straw $+10 \%$ Acacia albida pods (PRNTG10 + P0)

R3: Untreated rice straw $+15 \%$ Acacia albida pods (PRNTG15 + P0) 
R4: Untreated rice straw $+20 \%$ Acacia albida pods (PRNTG20 + P0);

R5: Untreated rice straw $+10 \%$ Acacia albida pods associated with PEG (PRNTG10 + P);

R6: Untreated rice straw $+15 \%$ Acacia albida pods associated with PEG (PRNTG15 + P);

R7: Untreated rice straw $+20 \%$ Acacia albida pods associated with PEG (PRNTG20 + P);

R8: Rice straw treated with ash extract (PRT: control 2)

R9: Rice straw treated with ash extract $+10 \%$ Acacia albida pods (PRTG10 + P0);

R10: Rice straw treated with ash extract $+15 \%$ pods of Acacia albida (PRTG15 + P0);

R11: Rice straw treated with ash extract $+20 \%$ pods of Acacia albida (PRTG20 + P0);

R12: Rice straw treated with ash extract $+10 \%$ Acacia albida pods associated with PEG (PRTG10 + P);

R13: Rice straw treated with ash extract $+15 \%$ Acacia albida pods associated with PEG (PRTG15 + P);

R14: Rice straw treated with ash extract $+20 \%$ Acacia albida pods associated with PEG (PRTG20 + P).

A $100 \mathrm{~g}$ sample of each ration was collected and stored for in vitro chemical composition and digestibility analyzes.

\subsection{Conduct of the Test}

\subsubsection{Collection of Rice Straw}

After collection, the rice straw was chopped manually in pieces of about 2 to $5 \mathrm{~cm}$, then dried and stored in the jute bags in a storied warehouse of the Research and Experimental Farm for the treatment of a portion of the ash extract.

\subsubsection{Collection of Acacia Albida Pods}

They were collected in the Koundoul area, $25 \mathrm{~km}$ from N'Djamena in Chad and packaged in bags for transport to Dschang where they were stored at the Research and Experimental Farm store.

\subsubsection{Preparation of Ash Extract and Treatment of Straw}

\section{Preparation of the ash extract}

The ash extract was obtained according to the method of [19]. The dried leaves of plantain (Musa paradisiaca) of the Giant french variety were harvested on the IRAD plots and burned on a concrete and clean surface of the FAR until the ashes were obtained. After cooling, the ash obtained was screened using a sieve. $8.5 \mathrm{~kg}$ of this sieved ash were collected and then dissolved in 85 liters of water. The mixture was homogenized and allowed to stand for 48 hours. The resulting solution was filtered using a clean cotton cloth to obtain our ash extract solution. The $\mathrm{pH}$ of the extract was measured before and after treatment of the rice straw using a EUTECH brand $\mathrm{pH}$ meter.

\section{Treatment of rice Straw}

For the treatment, $8.5 \mathrm{~kg}$ of rice straw, previously minced in small pieces and dried, were taken and then soaked in the extract solution overnight (12 hours). Thereafter, the straw was removed from the solution, dried in the sun until the solution completely disappeared and stored for the animals used.

\subsubsection{Analysis of the Mineral and Chemical Composition of Rations}

The analysis of the mineral composition of the ash extract solution, untreated and treated rice straw for the determination of the $\mathrm{Na}, \mathrm{K}, \mathrm{Ca}, \mathrm{P}, \mathrm{Mg}$ content was made according to the method described by [17].

Analyzes of the chemical composition of the different diets were carried out to determine dry matter (DM), ash, organic matter (OM), crude fiber, lipid, cell wall (NDF) and total nitrogenous matter (MAT) contents. These analyzes were made according to the methods described by [21].

\subsubsection{In Vitro Digestibility (Hohenheim Gas Test Method)}

i. Adaptation of the animal

The preparatory phase of the evaluation of in vitro digestibility lasted 10 days. During this phase, the animal received $800 \mathrm{~g}$ of feed daily alternately $400 \mathrm{~g}$ containing treated rice straw and $400 \mathrm{~g}$ containing untreated rice straw with ash extract associated or not with pods. The proportions of rice straws depended on the different levels of incorporation of crushed Acacia albida pods (10, 15 and $20 \%$ ).

ii. Preparation of samples and stock solution

For each ration, $500 \mathrm{mg}$ of samples were weighed in triplicate, using a KERN 770 electrical scale (210 g range and $0.001 \mathrm{~g}$ sensitivity), then deposited at the bottom of the syringes. Each sample was then covered by the piston of the syringe previously embalmed with Vaseline to facilitate its movement. The stock solution was prepared according to the method and procedure described by [15]. The different reagents used in the formulation of this solution and their volume are indicated in Table 1.

Table 1. Reagents used in the formulation of the solution and their volume.

\begin{tabular}{ll}
\hline Reagents & Volumes $(\mathbf{m l})$ \\
\hline Phosphate buffer & 333 \\
Macro minéral & 333 \\
Micro minéral & 0.333 \\
Rezasurine $0.4 \%$ & 0.417 \\
Distilled water & 732 \\
\hline
\end{tabular}

iii. Conditioning and incubation of samples and stock solution

Samples and freshly prepared solution according to the procedure described above were placed in a Memmert brand incubator at $39^{\circ} \mathrm{C}$ overnight. Similarly, the water bath was started and the temperature controlled by two LAUDA E300 brand thermostats set at $39^{\circ} \mathrm{C}$. In the morning before ruminal fluid collection, the solution was placed in the water bath at $39^{\circ} \mathrm{C}$. In this solution came continuously from a gas cylinder, a flow of $\mathrm{CO}_{2}$ whose pressure was set at 4 bar. Sodium sulfide $(417 \mathrm{mg})$ and $6 \mathrm{~N} \mathrm{NaOH}(0.444 \mathrm{ml})$ were added to the stock solution.

iv. Collection of ruminal fluid and incubation

Ruminal fluid was collected just after the goat was slaughtered at the laboratory level. Collection was done directly 
at the level of the rumen; this liquid was immediately filtered under a stream of $\mathrm{CO} 2$ that continually arrived from a gas cylinder. For the preparation of $2100 \mathrm{ml}$ of inoculum, $700 \mathrm{ml}$ of this liquid were taken and introduced into the stock solution still under the flow of $\mathrm{CO} 2$. This mixture (inoculum) was homogenized for 10 minutes using a magnetic rod. $40 \mathrm{ml}$ of this inoculum were collected and injected into each syringe using a Fortuna Optifix brand precision dispenser, and then the assembly was placed in the water bath for incubation.

The incubation lasted 24 hours and the volumes of gas produced were recorded at $0,3,6,9,12,18$ and $24 \mathrm{~h}$. Gas production was calculated and corrected according to the following formula (1) proposed by [15].

$$
G P(m l / 500 m g M S)=\frac{\left(V_{24}-V_{o}-G P_{o}\right) \times 500 m g \times G P_{h}}{m \times M S}
$$

With:

V24 = Volume of gas read after 24 hours of incubation;

$\mathrm{V0}=$ Volume of the inoculum in the syringe at the beginning of the incubation;

GP0 $=$ Volume of gas produced by the blank after 24 hours of incubation;

$\mathrm{GPh}=$ Volume of gas produced by the standard after 24 hours of incubation.

v. Evaluation of in vitro Digestibility of Dry Matter (DIVMS)

At the end of the incubation, the contents of the syringes were emptied into $600 \mathrm{ml}$ beakers. These syringes were rinsed twice with two $15 \mathrm{ml}$ portions of Neutral detergent solution (NDS) and emptied into beakers. The samples were boiled on a low heat for one hour and filtered through preweighed filter crucibles. These crucibles were pre-dried at $103^{\circ} \mathrm{C}$ overnight and weighed.

This operation made it possible to subtract the more or less non-degraded substrates and the micro-organisms which, when they are dead, are generally reused in the digestive tract of ruminants. The DIVMS was obtained by the difference between the weight of the incubated substrate and the weight of the undegraded residue after the NDS treatment at the end of incubation (1) from the following formula [21]:

$$
\text { DIVMS }(\%)=\frac{\mathrm{Pe}-\mathrm{R}}{\mathrm{Pe}} \times 100
$$

where:

$\mathrm{Pe}=$ weight of the incubated sample;

$\mathrm{R}=$ weight of the sample after incubation.

vi. Evaluation of in vitro digestibility of organic matter (DIVMO) and metabolizable energy (ME)

After 24 hours of incubation, the gases produced and corrected by the control tube gases were used to calculate the in vitro digestibility of organic matter (DIVMO) (3) using the regression equation of [15]. Metabolizable energy (ME) was calculated (4) using the equation proposed by [14].

$$
\begin{array}{r}
\operatorname{DIVMO}(\%)=14.88+0.889 \mathrm{GP}+0.0651 \mathrm{C} \\
\mathrm{EM}(\mathrm{MJ} / \mathrm{Kg} \mathrm{MS})=2.20+0.136 \mathrm{GP}+0.057 \mathrm{~PB}
\end{array}
$$

with:

GP = Quantity of gas produced after 24 hours of incubation;

$\mathrm{PB}=$ crude protein;

$\mathrm{C}=$ Ashes.

vii. Determination of partitioning factor, microbial mass, and volatile fatty acids

The partitioning factor (FC) that the amount of organic matter fermented to produce $1 \mathrm{ml}$ of gas was calculated from the following formula [14]:

$$
\mathrm{FC}(\mathrm{mg} / \mathrm{ml})=\frac{M O D}{G P}
$$

where: MOD $(\mathrm{mg})=$ Degraded Organic Matter;

GP $(\mathrm{ml})=$ Quantity of gases produced after 24 hours of incubation.

The microbial mass was calculated from the following formula [14]:

$$
\mathrm{MM}(\mathrm{mg})=\mathrm{MOD}-(\mathrm{GP} \times \mathrm{FS})
$$

with:

MOD $(\mathrm{mg})=$ Degraded organic matter;

GP $(\mathrm{ml})=$ Amount of gas produced after 24 hours of incubation;

$\mathrm{FS}=$ stoichiometric factor (2.20 for forage).

Volatile Fatty Acids (VFA) were obtained by calculation from the following formulas [14]:

$$
\operatorname{AGV}(\mathrm{mmol} / \mathrm{ml})=0.0239 \mathrm{GP}-0.0601
$$

(in the absence of PEG)

$$
\mathrm{AGV}(\mathrm{mmol} / \mathrm{ml})=0.0207 \mathrm{GP}+0.0207
$$

(in the presence of PEG)

Where: GP $(\mathrm{ml})=$ Amount of gas produced after 24 hours of incubation.

\subsection{Calculated Parameters}

The incubation of the different forage samples made it possible to calculate the following parameters:

1. Gas production (GP);

2. Volatile fatty acids (VFA);

3. Metabolizable energy (ME);

4. The partitioning factor (FC);

5. Microbial mass (MM);

6. In vitro digestibility of organic matter (DIVMO);

7. In vitro digestibility of dry matter (DIVMS).

\subsection{Statistical Analyzes}

In vitro digestibility data was subjected to one-way analysis of variance (ANOVA) using the General Linear Model (GML) with SPSS 20.0 statistical software. The statistical model was as follows:

Yij $=\mu+\alpha i+$ eij,

Where,

Yij $=$ observation on the animal $\mathrm{i}$ having received rations $\mathrm{i}$; $\mu=$ general average; 
$\alpha \mathrm{i}=$ effect of ration $\mathrm{i}$;

eij $=$ residual error on the ruminal fluid $i$ having incubated the ration $i$.

When differences existed between different treatments, the averages were separated by the Duncan test at $5 \%$ significance.

\section{Results and Discussion}

\subsection{Results}

\subsubsection{Mineral Composition of Treated or Untreated Rice Straw and Ash Extract Solution of Banana-plantain Leaves Before and After Treatment}

The mineral content and $\mathrm{pH}$ decreased in the ash extract after soaking. Moreover, it increases the content of these various minerals and the $\mathrm{pH}$ in the rice straw treated. In fact, the treatment with ash extract led to an increase in sodium (801 to $900 \mathrm{mg} / \mathrm{kg}$ ), phosphorus (1537.45 mg/kg), calcium (2440 to $11520 \mathrm{mg} / \mathrm{kg}$ ), magnesium (1243 to $1410 \mathrm{mg} / \mathrm{kg}$ ) and potassium (5951.75 to $10276.75 \mathrm{mg} / \mathrm{kg}$ ) content. The treatment with ash extract led to an increase in sodium (801 to $900 \mathrm{mg} / \mathrm{kg})$, phosphorus $(1537.45 \mathrm{mg} / \mathrm{kg})$, calcium $(2440$ to $11520 \mathrm{mg} / \mathrm{kg}$ ), magnesium (1243 to $1410 \mathrm{mg} / \mathrm{kg}$ ) and potassium (5951.75 to $10276.75 \mathrm{mg} / \mathrm{kg}$ ) content.

\subsubsection{Effect of Acacia Albida Pods with or Without PEG on Gas Production and in Vitro Digestibility of Different Rations}

i. Gas production

The evolution Gas production was similar for all rations. However, the highest values were recorded with diets containing PEG, particularly with $20 \%$ pods (PRNTG20P) and the lowest with PRNT without pods or PEG (Figure 1).

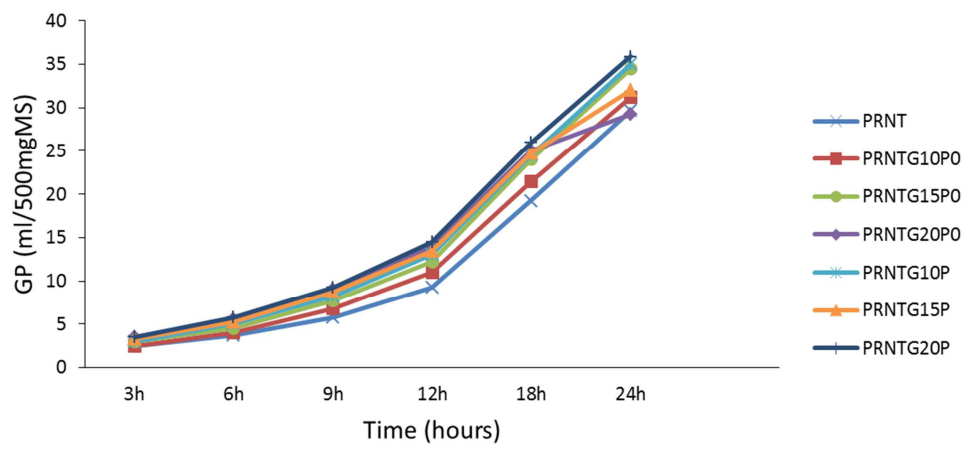

Figure 1. Effect of Acacia albida pods with or without PEG on the evolution of in vitro gas production of untreated rice straw as a function of time.

PRNT: untreated rice straw; PRNTG10P0: untreated rice straw plus 10\% Acacia albida pods without PEG; PRTG15P0: treated rice straw plus 15\% Acacia albida pods without PEG; PRTG20P0: treated rice straw plus 20\% Acacia albida pods without PEG; PRNTG10P: Untreated rice straw plus $10 \%$ Acacia albida pods with PEG; PRNTG15P: Untreated rice straw plus 15\% Acacia albida pods with PEG; PRNTG20P: Untreated rice straw plus 20\% Acacia albida pods with PEG; PEG: Polyethylene Glycol; GP: Gas Produced.

\section{ii. In vitro digestibility}

Generally, the gases produced in 24 hours (GP), organic matter digestibility (DIVMO) and metabolizable energy (ME) were influenced ( $\mathrm{p}<0.05)$ by increasing levels of Acacia albida pods and the addition of PEG (Table 2). The highest values were obtained with the ration PRNTG20P (respectively 31.70, 46.30 and 6.84). On the other hand, globally comparable values ( $\mathrm{p}>$ 0.05 ) were obtained with dry matter digestibility (DIVMS), microbial mass (MM), partitioning factor (FC), AGV and residual nitrogen (NDF-N). The highest value was recorded with the PRNTG20P ration.

Table 2. Effect of A. albida pods with or without PEG on in vitro digestibility parameters of untreated rice straw incubated with goat ruminal fluid.

\begin{tabular}{|c|c|c|c|c|c|c|c|c|}
\hline \multirow[b]{2}{*}{ Rations } & \multicolumn{8}{|l|}{ Parameters } \\
\hline & GP (ml/500mg MS) & DIVMS (\%) & DIVMO (\%) & $\begin{array}{l}\text { EM (MJ/kg } \\
\text { MS) }\end{array}$ & FC (mg/ml) & MM (mg) & $\operatorname{AGV}(\mathrm{mmol} / \mathrm{ml})$ & NDF-N (\%) \\
\hline$\overline{P R N T}$ & $25.25^{\mathrm{c}}$ & $47.41^{\mathrm{a}}$ & $39.46^{\mathrm{c}}$ & $5.82^{\mathrm{c}}$ & $2.33^{\mathrm{a}}$ & $182.43^{\mathrm{a}}$ & $0.53^{\mathrm{a}}$ & $0.88^{\mathrm{a}}$ \\
\hline PRNTG10P0 & $26.94^{\text {bc }}$ & $45.95^{\mathrm{a}}$ & $41.05^{\mathrm{bc}}$ & $6.06^{\mathrm{bc}}$ & $2.21^{\mathrm{a}}$ & $171.38^{\mathrm{a}}$ & $0.58^{\mathrm{a}}$ & $0.79^{\mathrm{a}}$ \\
\hline PRNTG15P0 & $30.21^{\mathrm{a}}$ & $46.25^{\mathrm{a}}$ & $44.44^{\mathrm{a}}$ & $6.57^{\mathrm{a}}$ & $2.06^{\mathrm{a}}$ & $166.03^{\mathrm{a}}$ & $0.66^{\mathrm{a}}$ & $0.75^{\mathrm{a}}$ \\
\hline PRNTG20P0 & $24.98^{c}$ & $45.16^{\mathrm{a}}$ & $40.33^{\mathrm{bc}}$ & $5.93^{\mathrm{c}}$ & $2.28^{\mathrm{a}}$ & $171.52^{\mathrm{a}}$ & $0.53^{\mathrm{a}}$ & $0.81^{\mathrm{a}}$ \\
\hline PRNTG10P & $30.75^{\mathrm{a}}$ & $44.16^{\mathrm{a}}$ & $44.44^{\mathrm{a}}$ & $6.58^{\mathrm{a}}$ & $1.97^{\mathrm{a}}$ & $153.83^{\mathrm{a}}$ & $0.65^{\mathrm{a}}$ & $0.79^{\mathrm{a}}$ \\
\hline PRNTG20P & $31.70^{\mathrm{a}}$ & $47.90^{\mathrm{a}}$ & $46.30^{\mathrm{a}}$ & $6.84^{\mathrm{a}}$ & $2.11^{\mathrm{a}}$ & $170.24^{\mathrm{a}}$ & $0.67^{\mathrm{a}}$ & $0.92^{\mathrm{a}}$ \\
\hline$p$ & 0.049 & 0.851 & 0.049 & 0.049 & 0.412 & 0.773 & 0.056 & 0.550 \\
\hline ESM & 0.6 & 0.51 & 0.55 & 0.08 & 0.03 & 2.81 & 0.01 & 0.01 \\
\hline
\end{tabular}




\subsubsection{Effect of Acacia Albida Pods, with or Without PEG, on Gas Production and in Vitro Digestibility of Straw Treated with Ash Extract \\ i. Gas production}

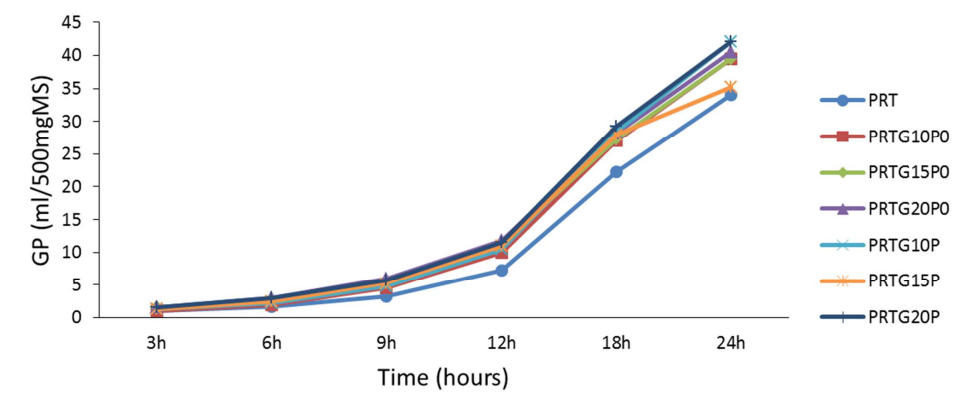

Figure 2. Effect of Acacia albida pods with or without PEG on the evolution of in vitro gas production of treated rice straw as a function of time.

PRT: treated rice straw; PRTG10P0: treated rice straw plus 10\% Acacia albida pods without PEG; PRTG15P0: treated rice straw plus $15 \%$ Acacia albida pods without PEG; PRTG20P0: treated rice straw plus $20 \%$ Acacia albida pods without PEG; PRTG10P: treated rice straw plus $10 \%$ Acacia albida pods with PEG; PRTG15P: treated rice straw plus 15\% Acacia albida pods with PEG; PRTG20P: Rice straw treated plus $20 \%$ pods of Acacia albida with PEG; PEG: Polyethylene Glycol; GP: Gas Products

The highest values were obtained with the PRTG20P ration and the lowest with the PRT diet without pods or PEG.

\section{ii. In vitro digestibility}

The effect of A. albida pods with or without PEG on in vitro digestibility parameters of treated straw incubated with goat ruminal fluid is presented in Table 3 . It shows that for all parameters except the DIVMS, partitioning factor (FC), microbial mass (MM) and residual nitrogen (NDF-N) for which thieves were broadly comparable ( $p>0.05)$, all other parameters were influenced $(\mathrm{p}<0.05)$ by the addition of increasing levels of $A$. albida pods especially when associated with PEG. The highest values were obtained with the PRTG20P ration.

Table 3. Effect of A. albida pods with or without PEG on in vitro digestibility parameters of treated straw incubated with goat ruminal fluid.

\begin{tabular}{|c|c|c|c|c|c|c|c|c|}
\hline \multirow{2}{*}{ Rations } & \multicolumn{8}{|l|}{ Parameters } \\
\hline & GP (ml/500mg MS) & DIVMS (\%) & DIVMO (\%) & EM (MJ/kg MS) & FC (mg/ml) & MM (mg) & AGV (mmol/ml) & NDF-N (\%) \\
\hline $\begin{array}{l}\text { PRT } \\
\end{array}$ & $29.20^{\mathrm{b}}$ & $55.12^{\mathrm{a}}$ & $43.28^{\mathrm{b}}$ & $6.33^{\mathrm{b}}$ & $2.56^{\mathrm{a}}$ & $213.25^{\mathrm{a}}$ & $0.63^{\mathrm{b}}$ & $0.79^{\mathrm{a}}$ \\
\hline PRTG10P0 & $34.79^{\mathrm{a}}$ & $55.88^{\mathrm{a}}$ & $48.89^{\mathrm{a}}$ & $7.18^{\mathrm{a}}$ & $2.34^{\mathrm{a}}$ & $205.95^{\mathrm{a}}$ & $0.77^{\mathrm{a}}$ & $1.01^{\mathrm{a}}$ \\
\hline PRTG15P0 & $35.06^{\mathrm{a}}$ & $57.64^{\mathrm{a}}$ & $49.41^{\mathrm{a}}$ & $7.26^{\mathrm{a}}$ & $2.41^{\mathrm{a}}$ & $211.36^{\mathrm{a}}$ & $0.77^{\mathrm{a}}$ & $0.69^{\mathrm{a}}$ \\
\hline PRTG20P0 & $35.93^{\mathrm{a}}$ & $57.68^{\mathrm{a}}$ & $50.17^{\mathrm{a}}$ & $7.38^{\mathrm{a}}$ & $2.39^{\mathrm{a}}$ & $211.61^{\mathrm{a}}$ & $0.79^{\mathrm{a}}$ & $0.67^{\mathrm{a}}$ \\
\hline PRTG10P & $37.39^{\mathrm{a}}$ & $53.90^{\mathrm{a}}$ & $51.19^{\mathrm{a}}$ & $7.53^{\mathrm{a}}$ & $2.16^{\mathrm{a}}$ & $189.40^{\mathrm{a}}$ & $0.79^{\mathrm{a}}$ & $0.67^{\mathrm{a}}$ \\
\hline PRTG15P & $34.38^{\mathrm{a}}$ & $54.64^{\mathrm{a}}$ & $48.80^{\mathrm{a}}$ & $7.16^{\mathrm{a}}$ & $2.34^{\mathrm{a}}$ & $199.85^{\mathrm{a}}$ & $0.73^{\mathrm{a}}$ & $0.79^{\mathrm{a}}$ \\
\hline$p$ & 0.014 & 0.167 & 0.014 & 0.014 & 0.134 & 0.195 & 0.019 & 0.361 \\
\hline ESM & 0.68 & 0.46 & 0.65 & 0.1 & 0.03 & 2.89 & 0.01 & 0.02 \\
\hline
\end{tabular}

a, b, c, d: averages with the same letter in the same column are statistically comparable to the $5 \%$ threshold.

PRT: treated rice straw; PRTG10P0: treated rice straw plus 10\% Acacia albida pods without PEG; PRTG15P0: treated rice straw plus $15 \%$ Acacia albida pods without PEG; PRTG20P0: treated rice straw plus 20\% Acacia albida pods without PEG; PRTG10P: treated rice straw plus $10 \%$ Acacia albida pods with PEG; PRTG15P: treated rice straw plus 15\% Acacia albida pods with PEG; PRTG20P: Rice straw treated plus 20\% pods of Acacia albida with PEG; P: Probability; E: Standard deviation; ESM: Average Standard Error; GP: Gas Products in 24 hours; DIVMS = In vitro digestibility of dry matter; FC = partition factor; DIVMO = In vitro digestibility of organic matter; NDF-N = Residual nitrogen; PEG: Polyethylene Glycol.

\subsection{Discussion}

The mineral content decreased in the ash extract after soaking. These observations corroborate those of [12] and [19] who treated rice straw respectively at the 25,28 and $10 \%$ ash extracts. Indeed, the decrease in the mineral content in the ash extract after soaking, correlated with its increase in treated rice straw, shows that the latter absorbed the minerals contained in the extract during the treatment [17]. Also, the drop in $\mathrm{pH}$ (12.4 to 10.9) in the ash extract after soaking rice straw confirms the observations made by [15] when soaking the rice straw in the $25 \%$ ash extract solution and observed a drop in $\mathrm{pH}$ (13.40 to 12.25).
The chemical composition of the diets was influenced by the ash extract treatment and the different levels of incorporation of $A$. albida pods. Levels of organic matter (OM), total nitrogen content (MAT), total carbohydrates (GT), lipids and NDF decreased after treatment. On the other hand, dry matter (DM) and ash contents increased with the treatment. The increase in ash content is consistent with observations of [11] who respectively treated straw with 3,5 and $8 \%$ ash extract of Trianthema pentandra, the hay of Chloris gayana at different levels of ash extract of banana leaves ( Musa sapientum) and rice straw at different levels (50, 100 and $150 \mathrm{~g}$ ) of banana plantain extract (Musa 
paradisiaca). However, the decrease in lipid content with the treatment is contrary to the results obtained by these authors. This would be due to the ability of the ash extract to solubilize the lipids thus facilitating their leaching by the ash extract. The decrease in the fiber content (NDF) observed in this study is due to the alkaline power of the ash extract solution to break the lignocellulosic bonds present in the cell walls of the straw with the corollary, the release of carbohydrates usable by microorganisms. The decrease in the total nitrogen content (MAT) is contrary to that of [1] when they treated the Hay of Rhodes grass with banana ash extract. This could be explained by the leaching of a part of the MAT by the ash extract solution, the quality of the latter, which is also affected by several factors, such as the fuel used for ash, the medium of the latter, the season, the stage of development and the type of plant material used during the treatment. The increase of the MAT content after the addition of $A$. albida pods is related to the richness of the latter in proteins.

The parameters of in vitro digestibility of treated rice straw, supplemented with different levels of $A$. albida pods with or without PEG, and incubated with goat ruminal fluid were significantly $(\mathrm{p}<0.05)$ affected. The production of $24 \mathrm{~h}$ gas and fatty acid of the treated rice straw was improved with the addition of $A$. albida pods with or without PEG, regardless of the ration considered. These results are in agreement with those obtained by [16] who respectively treated rice straw at $10 \%, 10 \%$ and different levels of ash extract from banana-plantain leaves supplemented respectively with the leaves of Calliandra calothyrsus, Arachis glabrata and Calliandra calothyrsus and incubated with goat ruminal fluid. However, these results are superior to those obtained by these authors. This difference would be due to the species and part of the legume used as nitrogen supplement. The increase in gas production would be related to the decrease in MM, as noted by [15] who observed that forages with high gas production have low microbial mass.

The DIVMS of rice straw treated with ash extract $(55.12 \%$ for the PRT ration without pods of $A$. albida or PEG) was significantly $(\mathrm{p}<0.05)$ increased compared to that of straw untreated rice (47.41\% for the PRNT diet without pods of $A$. albida or PEG). This observation is consistent with those obtained by [17] (44\% and $37.4 \%$ respectively) with wheat straw treated with $30 \%$ ash extract for untreated and treated rice straw rations without Arachis glabrata or PEG) with rice straw treated with $10 \%$ ash extract incubated with goat ruminal fluid. However, these results are superior to those reported by these authors. This difference could be explained by the type and stage of harvest of the straw, but also the type and origin of the fuel used for the preparation of the ash extract. The high value of DIVMS in rice straw treated with ash extract results from the rumen microorganisms' use of the minerals provided by this treatment. In fact, rumen bacteria use minerals for their growth and the maintenance of their cellulolytic activity. The addition of $A$. albida pods with or without PEG to treated or untreated rice straw had no significant effect $(p>0.05)$ on the DIVMS of the different diets. This observation is contrary to those recorded by [16] when associated with treated or untreated rice straw, the leaves of leguminous with or without PEG. This difference would be due to the species and part of the legume used as nitrogen supplement.

The DIVMO and the ME from the rice straw were significantly $(\mathrm{p}<0.05)$ improved by the ash extract treatment and the addition of $A$. albida pods with or without PEG. These results are in agreement with those obtained by [8] who showed that the increase in EM induces an increase in DIVMO. This could be explained by the improvement of the digestibility of the cell walls of the straw by the alkaline treatment with release of the energy contained in the carbohydrates, essential for microorganisms, the production of AGV and the microbial cells. Indeed, the more the OM is degraded, the more energy is produced.

Treatment significantly $(\mathrm{p}<0.05)$ improved microbial mass (MM) compared to untreated rice straw. However, the addition of Acacia albida pods slightly decreased MM even more when paired with PEG. This result confirms that obtained by [18] who showed a decrease in microbial mass by incubating $C$. calothyrsus with grasses in the presence of PEG.

Treatment and addition of Acacia albida pods with or without PEG did not significantly $(\mathrm{p}>0.05)$ significantly affect the partitioning factor (FC). However, FC values recorded with treated rice straw were slightly improved compared to those obtained with untreated rice straw. These values are lower than those of conventional foods $(2.74$ and $4.65 \mathrm{mg} / \mathrm{ml}$ ) obtained by [1] and tannin-rich forages ranging from 3.1 to $16 \mathrm{mg} / \mathrm{ml}$ [6]. This would be due to the high content (11.3\% DM) in tannins of Acacia albida pods. In this regard, the work of [9] showed that tannins reduce protein digestibility by $44 \%$.

Treatment with ash extract and the addition of Acacia albida pods with or without PEG significantly decreased ( $\mathrm{p}$ $<0.05)$ the residual nitrogen content $(\mathrm{NDF}-\mathrm{N})$. This result corroborates those obtained by [16] when she incubated rice straw associated with Calliandra associated with PEG. However, the values recorded are higher than those obtained by this author. This could be explained by the difference in legume used as nitrogen supplement. Indeed, the nitrogen content, antinutritional factors (lignin, silica, tannins), varies from one legume to another.

\section{Conclusion}

At the end of this study, concerning the effect of Acacia albida pods associated with polyethylene glycol on the in vitro digestibility of treated and untreated rice straw with banana leaf plant ash extract incubated with ruminal fluid goat, it appears that:

1. The treatment with the extract of center made it possible to increase the mineral content of the rice straw.

2. In addition, treatment with ash extract decreased dry matter (DM), organic matter (OM), total nitrogenous 
matter (MAT) and total carbohydrate (GT) levels while increasing the ash content, crude cellulose and cell walls of rations. On the other hand, the addition of Acacia albida pods improved the levels of MAT and MAD.

3. However, supplementation of rice straw with Acacia albida pods with or without PEG significantly $(\mathrm{p}<0.05)$ influenced all in vitro digestibility parameters of treated and untreated rice straw;

4. Except residual nitrogen, ash extract treatment and the addition of Acacia albida pods particularly associated with PEG have improved all other parameters of in vitro digestibility.

\section{References}

[1] Blümmel M., Makkar HPS, Chisanga G., Mtimuni J. and Becker K., 1997. The prediction of dry matter intake of temperate and tropical roughages from in vitro digestibility / gas-production data, and the dry matter intake and in vitro digestibility of African roughages in relation to ruminant liveweight gain. Animal Feed Science Technology, 69: 131-141.

[2] Breman H., Ridder D. N., 1991. Manual on Sahelian Pastures. Ed Karthala, ACCT CARBO-DLO and -CTA: $485 \mathrm{p}$.

[3] Chenost M. and Kayouli C., 1997. Use of roughage in warm regions. FAO Study, Production and Animal Health. $135 \mathrm{p}$.

[4] Dah S., 2009. Study of the production of Prosopis Africana pods and their valuation in animal feed. Polytechnic University Of Bobo-Dioulasso. No. 002009 (Elev), 83p.

[5] Fall ST, Traore EH, N'Diaye K., N'Diaye NS, Sèye BM, 1997. Use of Faidherbia albida fruits for cattle feeding: peasant fattening in the groundnut basin in Senegal, Livestock Research for Rural Development 1997, Volume 9, Number 5, 17p.

[6] Getachew G., Makkar H. P. S. and Becker K., 2000a. In vitro microbial fermentation and microbial protein synthesis. Journal of Agricultural and Food Chemistry, 48: 3581-3588.

[7] Grouzis M. and Akpo E. L., 2006. Tree-grass interactions in the Sahel. University Cheikh Anta Diop. Sechesse 2006; 17 (1-2): 318-25.

[8] Guerin H., 1999. Nutritional value of cultivated fodder. In: Guy Roberge and Bernard Toutain (eds). Tropical forage crops. Pp. 93-146.

[9] Hanley T. A., Robbins C. T., Hagerman A. F., McArthur C., 1992. Predicting digestible protein digestible garlic dry matter in tannin-containing lotings consumed by ruminants. Ecology. 73 (2). 537-541.

[10] Jouany J. P., Broudiscou L., Prins R. A. and KomisarczukBony S., 1995. Metabolism and nutrition of the microbial population of the rumen. In: Jarrige R., Ruckebush Y., Demarquilly C., Farce M. H., Journet M. (eds). Nutrition of domestic ruminants. INRA. Pp 349-381.
[11] Kanyinji F., Chongo J. and Simbaya J. 2014. Intake and Digestibility of Rhodes Grass (Chloris gayana) Hay Treated with Graded Levels of Concentration of Banana Ash Leaf Solution in Local Goats Journal of Advanced Animal Production., 4 (6): 448-454.

[12] Laswai G., Mtamakaya J., Kimambo A., Aboud A., Mtakwa P., 2007. Dry matter intake, in vivo nutrient digestibility and concentration of minerals in the blood and urine of steers. Animal Feed Science and Technology (137) 25-34.

[13] Lemoufouet J., Tendonkenf F., Miégoué E., Soumo S. N., Matumuini F. N. E., Fogang Zogang B., Mboko A. V., Mbainaissem B., Boukila B. and Pamo E. T., 2014. Ingestion and digestibility in sheep of corn stub treated with 5\% urea associated with molasses. Livestock Research for Rural Development 26 (3) 2014.

[14] Makkar H. P. S., 2002. Application of the in vitro method in the evaluation of feed resources, and enhancement of nutritional value of tannin-rich tree / browse leaves and agroindustrial by-products. In: Development and field evaluation of Animal Feed supplementation packages. IAEA Technical Co-operation Regional AFRA Project organized by the FAO / IAEA Joint Division of Nuclear Techniques in Food and Agriculture in Cairo, Egypt, 25-29 November 2000. Pp 23-40.

[15] Menke, K. H., and Steingass H., 1988. Estimation of the energetic feed obtained from chemical analysis and in vitro gas production using rumen fluid. Animal Research and Development, 28: 7-55.

[16] Ndonkou F. D. 2016. Effects of Calliandra calothyrsus associated with PEG on the in vitro digestibility of rice straws treated with ash extract in goats. Thesis submitted for the graduation of Master of Science in Animal Biotechnology and Production. University of Dschang, Faculty of Agronomy and Agricultural Sciences. 98p.

[17] Nolte M., Cline J., Dehority B., Loerch S., Parker C., 1987. Treatment of wheat straw with alkaline solutions prepared by wood ashes to improve fiber utilization by ruminants. Journal of Animal Science. 64: 669 to -677.

[18] Pamo T. E. Tendonkeng F. kana J. Loyem R. P. K., Tchapga E. and Fotie F. K. 2004. Effect of different levels of supplementation with Leucaena leucocephala on weight gain in Guinea fowl goat. Review of Livestock and Veterinary Medicine, 57 (2): 107-112.

[19] Rahman M., Akbar A., Islam S., Khaleduzzaman M. and Bostami R. 2009. Nutrient digestibility and growth rate of bull calves. Bang. Journal of Animal Science. 38 (1 \& 2): 42-52.

[20] Ramirez RG, Cruz F and Gonzalez CC (1992). Effects of treating corn as well as sodium hydroxide on nutrient digestibility by sheep and goats. Small Rumin. Res., 7: 225-233.

[21] Upreti C. R and Orden E. A., 2008. Effect of rice bran and Leucaena supplementation on the growth performance of fed with urea treated rice straw. Nepal Journal of Science and Technology 9 (2008) 29-36.

[22] Van Soest J. P. and Robertson J. B., 1985. Laboratory manual for animal Science. Cornelle University. New York, USA. 